\title{
A New Witness to the Fayyūmic Version of First Corinthians (P.MorganLib. 265). Part I: Notes on Codicology, Language, Provenance and Date
}

\author{
Ivan Miroshnikov
}

Swedish Collegium for Advanced Study, Linneanum, Thunbergsvägen 2, 75238 Uppsala, Sweden; Centre for Egyptological Studies, Russian Academy of Sciences, 29-8 Leninsky Avenue, Moscow, 119071, Russian Federation

Email: ivan.miroshnikov@gmail.com

\begin{abstract}
This is the first part of a two-part article focused on a fragmentary parchment codex, whose three extant leaves, designated in Leo Depuydt's catalogue as P.MorganLib. 265, are housed at the Morgan Library \& Museum in New York. These fragments bear witness to 1 Cor 2.12-3.18; 7.16-30; 15.3-30 in the 'classical' variety of Fayyūmic Coptic (dialect F5). Most of these verses have been hitherto unattested in Fayyūmic and thus allow us to attain better insight into the history and text of the Coptic Bible. In the first part of this article, I discuss the codicology of P.MorganLib. 265, its linguistic features, provenance and date.
\end{abstract}

Keywords: codicology; Coptic New Testament; Fayyūmic Coptic; First Letter to the Corinthians; Phantoou find

In memory of Wolf-Peter Funk, 1943-2021

\section{Fate of a Manuscript: Discarded, Recycled, Rediscovered}

The manuscript under discussion here, edited for the first time in this article, is part of the Phantoou find, a group of parchment codices that once belonged to the library of the Monastery of the Archangel Michael at Phantoou, an ancient site in the western part of the Fayyūm. The ruins of the monastery are located near the present-day village of al-Hāmūlì. The manuscripts were found in a stone cistern by a group of farmers in 1910. After having changed hands several times, most of the codices - forty-seven in total - were purchased by the famous American financier John Pierpont Morgan. Today, these manuscripts are housed at the Morgan Library \& Museum in New York. ${ }^{1}$

\footnotetext{
${ }^{1}$ For a detailed account of the discovery and acquisition of the Phantoou manuscripts, see L. Depuydt, Catalogue of Coptic Manuscripts in the Pierpont Morgan Library (2 vols.; Corpus of Illuminated Manuscripts 4-5; Leuven: Peeters, 1993) I.lviii-lxii.

(c) The Author(s), 2021. Published by Cambridge University Press. This is an Open Access article, distributed under the terms of the Creative Commons Attribution licence (http://creativecommons.org/licenses/by/4.0/), which permits unrestricted re-use, distribution, and reproduction, provided the original article is properly cited.
} 
The Phantoou manuscripts are large in size, which, as Stephen Emmel observes, 'shows that they were made for the purpose of public reading during church services'. ${ }^{2}$ Most of the codices are written in Sahidic Coptic and comprise various biblical, hagiographic and homiletic texts. One such codex - housed at the Morgan Library \& Museum under inventory number M.585 and designated in Leo Depuydt's catalogue as P.MorganLib. $166^{3}$ - is MICH.BM, ${ }^{4}$ which contains three texts in Sahidic: the Martyrdom of Leontius and Publius (cc 0519), Encomium on Leontius, attributed to Severus of Antioch (cc 0344) and Miracles of Menas (cc 0231). ${ }^{5}$ Like most of the Phantoou codices, MICH.BM was found in its original binding, made from papyrus boards and leather coverings. ${ }^{6}$ Leaves extracted from an older parchment codex were pasted down to the inside of the covers of the codex and are the sole remnants of the Fayyūmic manuscript designated in Depuydt's catalogue as P.MorganLib. $265 .^{7}$

Both paste-downs were made up of several parchment fragments, designated by Depuydt as frs. (a), (b), (c), (d) and (e). The upper paste-down was made up of frs. (a) and (b); the lower one of frs. (c), (d) and (e). Fr. (b) is a complete manuscript leaf, which I designate fol. (b). Frs. (c) and (a) join and make up a complete folio, which I designate fol. (c+a). Frs. (d) and (e) also join, forming the innermost side of the leaf, which I designate fol. $(d+e)$. The outermost side of fol. $(d+e)$ is lost. Both fol $(c+a)$ and the innermost side of fol. $(d+e)$ were probably cut in two at the bindery.

When making the paste-downs of MICH.BM, the binder needed to paste several parchment fragments together, because the covers of MICH.BM were larger than the untrimmed leaves of P.MorganLib. 265 and even more so in those cases when the edges of the leaves were trimmed by the binder. ${ }^{8}$ To produce the upper paste-down, the binder rotated frs. (a) and (b) by $180^{\circ}$ and attached the verso of fr. (a) to the recto of fr. (b), so that fr. (a) would extend fr. (b) from below. To make the lower pastedown, the binder attached fr. (c) to fr. (d), the recto of fr. (c) facing the verso of fr. (d) - both rotated by $90^{\circ}$ anticlockwise - so that fr. (d) would extend fr. (c) from above. He then attached fr. (e) to frs. (c) and (d), the recto of fragment (e) - also rotated by $90^{\circ}$

\footnotetext{
${ }^{2}$ S. Emmel, 'The Library of the Monastery of the Archangel Michael at Phantoou (al-Hamuli)', Christianity and Monasticism in the Fayoum Oasis (ed. G. Gabra; Cairo: American University in Cairo Press, 2005) 63-70, at 65. Cf. a similar observation already in H. Hyvernat, 'Coptic Literature', The Catholic Encyclopedia (16 vols.; ed. C. G. Herbermann; New York: Encyclopedia, 1907-14) xvi.27-30, at 28.

${ }^{3}$ Depuydt, Catalogue, i.335-7.

${ }^{4}$ Here and wherever possible, I refer to Coptic literary manuscripts using the sigla from the Corpus dei Manoscritti Copti Letterari database (www.cmcl.it/); in these sigla, the prefix 'MICH' designates the codices from the Monastery of the Archangel Michael. Non-biblical literary works in Coptic are identified by their 'clavis coptica' number (www.cmcl.it/ cmcl/chiam_clavis.html), hereafter 'cc'.

${ }^{5}$ All three of these texts are published; see J. Drescher, Apa Mena: A Selection of Coptic Texts Relating to St. Menas (Publications de la Société d'archéologie copte: Textes et Documents; Cairo: Société d'archéologie copte, 1946) 7396, 149-59; G. Garitte, 'Textes hagiographiques orientaux relatifs à Saint Léonce de Tripoli', Le Muséon 78 (1965) 313-48 and 79 (1966) 335-86.

${ }^{6}$ In scholarly literature, the boards, made of several layers of papyrus, are often termed 'cartonnage'. As Erja Salmenkivi notes, however, such a use of the term 'cartonnage' can be confusing, since, in Egyptology, 'cartonnage' refers to mummy masks, pectorals and foot covers; a more appropriate term would be 'stuffing' or 'packing'. See E. Wipszycka, 'The Nag Hammadi Library and the Monks: A Papyrologist's Point of View', The Journal of Juristic Papyrology 30 (2000) 179-91, at 186-7 ('stuffing'); R. S. Bagnall, Everyday Writing in the Graeco-Roman East (Sather Classical Lectures 69; Berkeley: University of California Press, 2011) 81 ('packing'); E. Salmenkivi, 'Reuse and Recycling of Papyrus', Recycling and Reuse in the Roman Economy (ed. C. N. Duckworth and A. Wilson; Oxford Studies on the Roman Economy; Oxford: Oxford University Press, 2020) 98.

${ }^{7}$ Depuydt, Catalogue, i.458-9.

${ }^{8}$ The upper cover of MICH.BM measures $337 \times 260 \mathrm{~mm}$; the lower cover, $329 \times 265 \mathrm{~mm}$. The original leaf size of P.MorganLib. 265 was ca $320 \times 253 \mathrm{~mm}$ (see the discussion below).
} 
anticlockwise - facing the rectos of frs. (c) and (d). Both paste-downs were then attached to the papyrus boards.

In 1912, the Morgan Phantoou codices were sent to the Vatican Library for restoration. There, the restorers separated the original binding of MICH.BM from its text block and its paste-downs from its covers. The manuscript, along with its covers and paste-downs, was photographed for the facsimile edition, published in 1922. ${ }^{9}$ Fragments of P.MorganLib. 265 were separated from each other, inlaid in modern parchment and bound together with the text block of MICH.BM. The codex then received modern binding, while the original binding received a new housing and was assigned a new inventory number - viz. M.585A. ${ }^{10}$ In the rebound codex M.585, the Fayyümic fragments occupy fols. i-ii and 50-1. This position reflects the one they had when they were pasted together; thus, frs. (a) and (b) are upside down, and frs. (c), (d) and (e) are rotated by $90^{\circ}$. For the same reason, the versos of frs. (c) and (d) precede their rectos. The correspondence between the division of Depuydt's fragments and the modern foliation is given below. ${ }^{11}$

\begin{tabular}{ll}
\hline Depuydt's fragments & Leaves \\
\hline Fr. (a) & Fol. i \\
\hline Fr. (b) & Fol. ii \\
\hline Fr. (c) & v-r \\
\hline Fr. (d) & Fol. 50 \\
\hline Fr. (e) & Fol. 51 (top) \\
\hline
\end{tabular}

In sum, P.MorganLib. 265 seems to have had a veritable afterlife. After it became worn out, this codex made its way to the binder's shop, where three of its leaves were reused as paste-downs of another codex, MICH.BM. This latter codex, along with many other manuscripts from the Monastery of the Archangel Michael, was eventually hidden in a stone cistern, where, centuries later, it was rediscovered by Egyptian farmers. Then, at the Vatican, the restorers removed the paste-downs from MICH.BM, separated the fragments of P.MorganLib. 265 from each other and rebound them with the rest of MICH.BM. It is in this state that the fragments are now available to researchers visiting the Morgan Library \& Museum in New York.

\section{Description of the Manuscript}

Having discussed the fate of P.MorganLib. 265, I now turn to a description of the manuscript and its contents. All three extant leaves of P.MorganLib. 265 comprise portions of Paul's First Letter to the Corinthians in Fayyūmic. It seems certain that, when the codex was intact, it contained the complete text of this letter. It is also plausible that the codex

\footnotetext{
${ }^{9}$ For photographs of the pastedowns, see [H. Hyvernat], Bybliothecae Pierpont Morgan codices coptici photographice expressi (56 vols., Rome: [s.n.], 1922) xxxvIII.3-4, 103-4. The photograph of the inner face of the lower cover (ibid., xxxviI.105) shows that, after the lower paste-down was removed from it, parts of frs. (c) and (e) were left stuck to the papyrus board.

${ }^{10}$ On the rehousing of the ancient bindings of the Morgan Phantoou codices, see G. Southworth and F. Trujillo, 'The Coptic Bindings Collection at the Morgan Library \& Museum: History, Conservation, and Access', The Book and Paper Group Annual 35 (2016) 89-95.

${ }^{11}$ The modern numbers of the folios of M.585 are inscribed on the upper-left corners of their rectos. Additionally, the lower-left corners of the rectos of fols. i-ii and 50-51 contain the following notes: ' 1 st flyleaf', '2- flyleaf', 'rear flyleaf no. 1', and 'rear flyleaf no. 2'.
} 
contained more than one text. Although it is impossible to ascertain what these lost texts might have been, the most likely possibility is that the codex comprised Pauline letters. ${ }^{12}$ The contents of each surviving page of P.MorganLib. 265 are summarised below.

\begin{tabular}{lc}
\hline Pages & Contents \\
\hline Fol. $(c+a)^{r}$ & I Cor 2.12-3.7 \\
\hline Fol. $(c+a)^{v}$ & I Cor 3.7-3.18 \\
\hline Fol. $(d+e)^{r}$ & I Cor $7.16-24$ \\
\hline Fol. $(d+e)^{v}$ & I Cor $7.24-30$ \\
\hline Fol. $(b)^{r}$ & I Cor $15.3-17$ \\
\hline Fol. $(b)^{v}$ & I Cor $15.17-30$ \\
\hline
\end{tabular}

The original page size of P.MorganLib. 265 can only be measured approximately. Fol. $(d+e)$ is of no use for this purpose, since it is missing not only its outermost side but also its upper margin. Fol. ( $c+a)$ is taller than fol. (b) $-320 \mathrm{~mm}$ vs $287 \mathrm{~mm}$ - and thus may preserve the manuscript's original upper and lower margins. Conversely, fol. (b) is broader than fol. (c+a) - $253 \mathrm{~mm}$ vs $234 \mathrm{~mm}$ - and thus possibly preserves the manuscript's original left and right margins. That the height and width of fols. $(c+a)$ and $(b)$ are different probably indicates that, before the fragments were pasted down, the edges of the leaves that had experienced natural deterioration were cut off.

None of the extant margins seems to preserve any page numbers, which most probably indicates that the three surviving leaves were not paginated. ${ }^{13}$ The text of the manuscript is divided into two columns. The longest columns - viz. col. ii of fol. $(\mathrm{d}+\mathrm{e})^{\mathrm{r}}$ and col. $\mathrm{i}$ of fol. $(d+e)^{v}-$ comprise forty-one lines; the shortest column - viz. col. i of fol. $(c+a)^{v}-$ thirtyseven lines.

The text is written in unimodular uncials. Vertical strokes are upright and thick and horizontal strokes thin, with curved strokes alternating between thicker and thinner segments (e.g., the letter o is written in one stroke, whose left and right edges are thick and upper and lower edges thin). The letters $z, p, \psi, a), \varphi$ and + extend below the baseline; the letter $\phi$ breaks the bilinearism both at the top and at the bottom.

Two letters have shapes attested only in Fayyümic manuscripts - viz. $\alpha$ ) and $\sigma$. The letter a) seems to be written in three strokes, with a thick vertical stroke connected to a finned stroke at the top and a horizontal stroke at the bottom; the horizontal line stretches to the left then takes a sharp turn and extends all the way back to the right. The letter $\sigma$ is usually written in two strokes, with a circle resembling the letter o and a diagonal stroke stretching from the lower edge of the circle to the right. However, in at least three instances, ${ }^{14}$ the scribe did not give the letter $\sigma$ this uniquely Fayyūmic

\footnotetext{
${ }^{12}$ Cf. P.MorganLib. 267 (Depuydt, Catalogue, I.461-2), another Fayyūmic manuscript extracted from the covers of the Phantoou codices, whose remaining fragment bears witness to the last verses of Paul's Letter to the Galatians and the first verses of his Letter to the Ephesians.

${ }^{13}$ Cf. P.Mich.inv. 158 (9) + P.MorganLib. 264, another Fayyūmic codex of Pauline epistles (though not part of the Phantoou discovery), whose fragments preserve some of the quire signatures, but no page numbers (see Depuydt, Catalogue, I.456-8).

141 Cor $7.21 ; 15.15,25$; this shape of $\sigma$ may have also occurred at 1 Cor 3.2 , where $\sigma$ is line-final and, unfortunately, has almost entirely vanished. It is worth noting that there is also a third shape for 6 , which occurs in the nomen sacrum $\pi \overline{\overline{C C}}$ ('the Lord'). In these instances, $\sigma$ is represented by a circle resembling the letter o, whose upper-right edge is connected with the upper-left edge of the letter c by means of a horizontal stroke.
} 
shape; instead, in these cases, the oblique stroke joins the left edge of the circle and stretches to the right, reaching the bottom of the preceding line.

There are two other letters in P.MorganLib. 265 written in two different shapes - viz. $a$ and $\boldsymbol{M}$. The letter $\mathrm{d}$ is usually made up of two thick oblique strokes connected at the top and joined by a thin oblique middle stroke at the bottom. However, occasionally the letter is shaped differently, with a thick vertical stroke joined to a curved stroke on the left and a thin horizontal stroke on the right; the horizontal stroke connects a with the following letter. As for the letter $M$, it seems to be always written in three strokes, usually with two thick vertical strokes connected by a curved middle stroke. Sometimes, however, $M$ is written in three concave strokes, the right stroke extending along the baseline and connecting to the following letter.

When it appears near or at the end of the line, the letter $\mathrm{T}$ is sometimes enlarged, its vertical stroke being written above the adjacent letters. For the same reason - i.e. to accommodate more text - when the combination or occurs at the end of the line, the let-

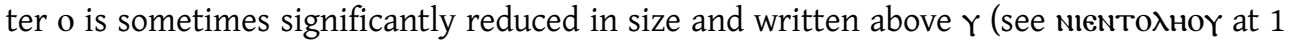
Cor 7.19 and nor|er at 1 Cor 7.20). Other letters written towards the end of the line can also be reduced in size; of those, $\mathrm{\varphi}$ is especially noteworthy (when it occurs at the end of the line, its vertical stroke is slightly elevated and its curved stroke very small, positioned above the bilinear space).

The new sections of text are marked with initials, which are often enlarged and written in ekthesis. The initials are always accompanied by paragraph marks, usually shaped as simple angular coronides $(>){ }^{15}$ Smaller textual units within paragraphs are separated from each other by means of middle dots. The middle dot also occurs on the last line of a paragraph, followed by a blank space. In one instance (at the end of verse 15.20), the middle dot is followed by a long horizontal stroke. The coronis, signalling the beginning of the following paragraph, is zeta-shaped, its lower branch growing into an ornament, with four spirals of identical size.

In at least six instances (imi at 1 Cor 2.14, а)шпi at 1 Cor 7.12 and 15.21, NaBi at 1 Cor 15.17, NiBi at 1 Cor 15.19 and 15.28), the scribe placed a dot above the letter 1 . It is noteworthy that, in all these instances, the dotted $ı$ is word-final and preceded by a consonant; this phenomenon is also attested in P.Mich.inv. 158 (9) + P.MorganLib. 264. The function of the dot is obscure.

The supralinear stroke is tilde-shaped and used only to signal abbreviations - i.e. the

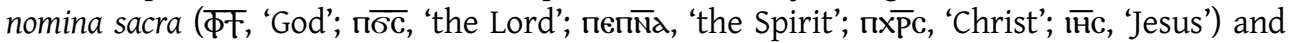
numbers ( $\bar{\Gamma}$, 'three'; $\overline{\mathrm{iB}}$, 'twelve'; $\Phi$, '500') - and to represent line-final $\mathrm{N}$ (e.g. $\alpha^{-}$' for $\mathrm{aN}$ in verse 15.21).

\section{History of Research}

The first to study P.MorganLib. 265 was Henri Hyvernat, the scholar responsible for the production of the facsimile edition of the Morgan codices, comprising fifty-six volumes. In the 'index tabularum' of vol. xxxviII (comprising M.585), Hyvernat mistakenly wrote that each of the two paste-downs was made up of two fragments, somewhat imprecisely identifying their contents (e.g. saying that fr. (b) comprised 1 Cor 15.4-31 - this mistake was later repeated by Depuydt). After the publication of the facsimile, Hyvernat must have occasionally revisited the manuscript, as his copy of vol. xxxviI housed at the Catholic University of America in Washington, DC contains numerous marks witnessing his attempts to trace the faded letters, identify the biblical verses and restore some of the lacunae. An entry on M.585 in his unpublished Catalogue of the Coptic Manuscripts in the

\footnotetext{
${ }^{15}$ For a typology of coronides, see e.g. Depuydt, Catalogue, I.cii.
} 
Pierpont Morgan Library ${ }^{16}$ includes a note on the 'fly leaves' (i.e. paste-downs), ${ }^{17}$ which, however, merely repeats what Hyvernat had written in the 'index tabularum'.

Although only thirteen copies of Hyvernat's facsimile were made and although the photographs of P.MorganLib. 265 printed therein were taken before the paste-downs were dismantled (meaning that portions of text were inaccessible to the reader), this publication still allowed Coptologists to make use of the manuscript. Thus, the text of P.MorganLib. 265 is occasionally referenced in W. E. Crum's Coptic Dictionary. Unfortunately, Crum's references to P.MorganLib. 265 are often indistinguishable from his references to codex C, both of which he designates with the siglum ' $F$ ' (i.e. 'Fayyūmic \& related dialects') - even though the language of the latter manuscript is better defined as 'unevenly Fayyūmicised Crypto-Sahidic'18 - and which happens to also contain 1 Cor 7.16-30 and 15.3-30. ${ }^{19}$ That is, Crum never specifies when a passage derives from codex C and only occasionally marks his references to P.MorganLib. 265 with 'Mor 38'. Thus, in his entry for 'circumcise', the stative севноүт and the construction al Nатснввı ('be uncircumcised'), which both come from codex C, are marked '1 Cor 7.18 $F^{\prime 20}{ }^{20}$ On the other hand, in his entry for 'have pity, mercy', the source of $x_{1}$ mחneel ('get pity, take alms') - marked ' 1 Cor $15.19 F^{\prime}$ - is P.MorganLib. $265 .^{21}$ The importance of P.MorganLib. 265 for Fayyūmic lexicography is further discussed in the following section (see pp. 14-15 below).

Later, P.MorganLib. 265 was briefly mentioned by Theodore C. Petersen in his unpublished monograph on Coptic bookbindings (written between 1929 and 1950) and by Paul E. Kahle in an appendix on the relationship between the Fayyūmic (fa) and the Bohairic (bo) version of the New Testament. ${ }^{22}$ Finally, Depuydt wrote an entry on this manuscript in his catalogue, which, although quite short, needs several corrections. For example,

\footnotetext{
${ }^{16}$ I consulted the hand-written copy housed at the Semitics/ICOR Library of the Catholic University of America.

${ }^{17}$ Hyvernat also erroneously used the term 'fly leaf' instead of 'paste-down' in his Check List of Coptic Manuscripts in the Pierpont Morgan Library (New York: 'privately printed', 1919) 14 ('2 fly-leaves').

${ }^{18}$ W.-P. Funk, ‘Formen und Funktionen des Interlokutiven Nominalsatzes in den koptischen Dialekten', Langues Orientales Anciennes. Philologie et Linguistique 3 (1991) 1-75, at 17 n. 38; cf. idem, 'Gedanken zu zwei faijumischen Fragmenten', Christianisme d'Égypte. Hommages à René-Georges Coquin (Cahiers de la Bibliothèque Copte 9; Paris: Peeters, 1995) 93-100, at 97 n. 13.

${ }^{19}$ The designations 'codex A', 'codex B' and 'codex C' refer to three fragmentary parchment codices comprising the Book of Isaiah (codex A), the Tetraevangelion (codex B) and the Pauline Epistles (codex C), which were once deposited at the library of the White Monastery; of those, the first two belong to the F5 corpus. The extant fragments of the three codices are divided between the Institut français d'archéologie orientale in Cairo, the National Library of France in Paris, the Vatican Apostolic Library in Rome, the Austrian National Library in Vienna and the University of Oslo (042/3, unpublished). The fragment of codex B housed at the University of Leuven was destroyed in 1940. See G. Zoega, Catalogus codicum copticorum manu scriptorum qui in Museo Borgiano Velitris adservantur (Rome: Sacra ongregatio de propaganda fide, 1810) 145-68; É. Chassinat, 'Fragments de manuscrits coptes en dialecte fayoumique', Bulletin de l'Institut Français d'Archéologie orientale 2 (1902) 171-206; K. Wessely, Ein Sprachdenkmal des mittelägyptischen (baschmurischen) Dialekts (Sitzungsberichte der Kaiserlichen Akademie der Wissenschaften in Wien. Philosophisch-Historische Klasse 158.1; Vienna: Hölder, 1908); A. Hebbelynck, 'Fragment fayoumique de la première Épître aux Corinthiens (1 Cor xv, 41-45, 53-54; xvI, 6-9, 16-20)', Le Muséon 35 (1922) 1-16; A. Bouvarel-Boud'hors, Catalogue des fragments coptes, vol. I: Fragments bibliques nouvellement identifiés (Paris: Bibliothèque Nationale, 1987) 91-7; eadem, 'Fragments du Nouveau Testament fayoumique à la Bibliothèque Nationale', Langues Orientales Anciennes: Philologie et Linguistique 1 (1988) 95-116; C. Louis, Catalogue raisonné des manuscrits littéraires coptes conservés à l'IFAO du Caire. Contribution à la reconstitution de la Bibliothèque du monastère Blanc (PhD diss.; Paris, École pratique des hautes études, 2005) 565-7.

${ }^{20}$ W. E. Crum, A Coptic Dictionary (Oxford: Clarendon, 1939) 322a.

${ }^{21}$ Crum, Coptic Dictionary, 217a.

${ }^{22}$ P. E. Kahle, Bala'izah: Coptic Texts from Deir el-Bala'izah in Upper Egypt (2 vols.; London: Oxford University Press, 1954) г.284 n. 5; T. C. Petersen, 'Coptic Bookbindings in the Pierpont Morgan Library' (unpublished typescript) 162.
} 
while he rightly observes that there are five fragments (rather than four), he fails to identify the contents of fr. (e) or notice that frs. (d) and (e) join together. The description of P.MorganLib. 265 provided in this article thus supersedes that by Depuydt.

\section{Language}

The consistent lambdacism of P.MorganLib. 265 - i.e. the substitution of /r/ with /1/ (e.g.

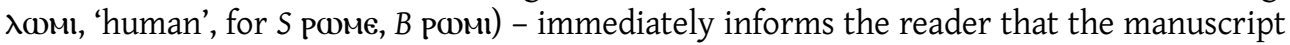
is written in a Fayyūmic dialect. The two major varieties of Fayyūmic Coptic are F4 (Early Fayyūmic) and F5 (Classical Fayyūmic). ${ }^{23}$ Although the dividing line between the two dialects is not as clear as we might wish it to be (i.e. F5 manuscripts often exhibit features characteristic of F4), the distinction still seems to be worth retaining. Wolf-Peter Funk has formulated several criteria for distinguishing between $F 4$ and $F 5,{ }^{24}$ according to which P.MorganLib. 265 should be classified as a witness to the latter dialect:

- The stem-final stressed front vowel of a word in prepersonal state, which in Sahidic and Bohairic is represented by $\mathrm{a}$, is represented by $\epsilon$ in $F 4$ and by $\mathrm{H}$ in $F 5$. In accordance with the $F 5$ standard, P.MorganLib. 265 always reads $\mathrm{NH}=$ ('to, for'; $S B \mathrm{N \alpha}=, F 4 \mathrm{NE}=$ ) and мємн= ('with'; $S$ ммммд=, B мємд=, F4 мємє三). This rule can be found also in operation in the verb $\mathbf{m e a )} \mathbf{H}=$ ('not to know'), which at verse 7.17 occurs as part of the conjunction ємє)н ('except').

- F5 signals the presence of a glottal stop / $/$ / after a stressed vowel by doubling the vowel grapheme $e^{25}$ - unlike $F 4$, which does not have any graphic expression for the glottal stop. P.MorganLib. 265 follows the F5 standard in reading, e.g. meel ('truth';

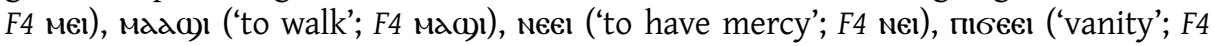

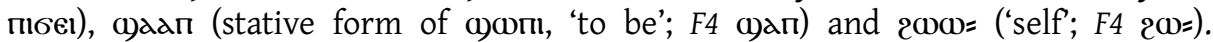
There are, however, also words spelled without vowel gemination whose form thus coincides with that in $F 4$ - viz. $\kappa \epsilon=$ (prepersonal form of $\kappa \omega$, 'to put'; cf. $\kappa \epsilon c$, 'in order that'), мноү ('to think'), оүєв ('holy'), оүєе ('one') and oүaєт= ('self'). It is worth noting, however, that, although other F5 manuscripts often geminate the stressed vowel in these words (thus кєє =, мнноү, оүєєв, оүєєl, and oүaєєт $=$ ), the F5 corpus is by no means uniform in this respect. As Funk notes, manuscripts that regularly employ forms like $\mathrm{NH}=$ and $\mathrm{N} \mathrm{MH}_{\mathrm{H}}$ yet exhibit certain inconsistency with regard to vowel gemination should still be classified as witnesses to $F 5{ }^{26}$

- In F4, the indefinite pronoun used in negative contexts is $\lambda a n+$, while $F 5$ either uses $\lambda$ גас or oscillates between $\lambda$ aпc and $\lambda$ ant. In accordance with the F5 standard, P.MorganLib. 265 consistently employs $\lambda$ anc.

- For the relative perfect, F4 usually employs $6 \mathrm{Td}-, \epsilon T d=$, while, in the F5 corpus, we predominantly encounter NTd-, NTd=. P.MorganLib. 265 always employs NTd-, NTd $=$, except for the hitherto unattested form $6 T d d=$, which appears to be reserved for instances where the relative perfect occurs in the 'glose' of a cleft sentence (see the discussion below).

\footnotetext{
${ }^{23}$ These are the sigla assigned to Coptic dialects by Wolf-Peter Funk and Rodolphe Kasser; see R. Kasser, 'A Standard System of Sigla for Referring to the Dialects of Coptic', Journal of Coptic Studies 1 (1990) 141-51.

${ }^{24}$ For the first three criteria listed below, see W.-P. Funk, 'Der Anfang des Johannesevangeliums auf faijumisch', Archiv für Papyrusforschung und verwandte Gebiete 34 (1988) 33-42, at 34. The last two criteria I drew from my personal communication with Funk.

${ }^{25}$ This appears to be the most likely phonological interpretation for Coptic vowel gemination; cf. W.-P. Funk and R. Smith, 'John 10:7-13:38 in Subachmimic', The Chester Beatty Codex Ac. 1390: Mathematical School Exercises in Greek and John 10:7-13:38 in Subachmimic (ed. W. Brashear; Leuven: Peeters, 1990) 59-95, at 70.

${ }^{26}$ Funk, 'Anfang des Johannesevangeliums', 34-5.
} 
- In F4, the definite plural article is usually $\mathrm{NI}^{-}$; in F5, N6-. In P.MorganLib. 265, the form Ne- occurs only twice (1 Cor $15.3,4)$, both times in the expression каTd меграфн ('according to the scriptures'). In all other instances, the manuscript has $\mathrm{NI}-$. Just like the occasional absence of vowel gemination, this preference for NI- should probably be interpreted in the light of the fact that the transition from the 'early' norm of Fayyumic (F4) to the 'classical' one (F5) is likely to have been a long and gradual process.

In sum, despite some notable departures from what can reasonably be conceived of as the dialectal norm, the dialect of P.MorganLib. 265 is undoubtedly F5.

In what follows, I briefly discuss the orthographic and morphological features of the manuscript, its treatment of Greek loanwords and, finally, its significance for Coptic lexicography.

Overall, the orthography of P.MorganLib. 265 is quite consistent and compliant with what seems to be the standard Fayyūmic scribal practice - for example, the grapheme $<\mathrm{i} / \mathrm{y}>$ is always represented by $ı$. There are, however, several orthographic features that are worthy of note.

- The definite singular article $\pi^{-}, \mathbf{T}$ - usually has the long form (viz. $\pi \epsilon^{-}$, , тє-) if the determined noun begins with two consonants - hence пєемдт ('the grace') and

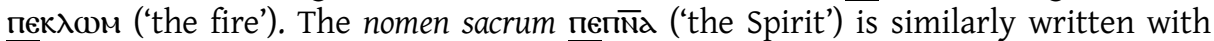
the long article. Yet the long form is never employed with the nomen sacrum nxpc

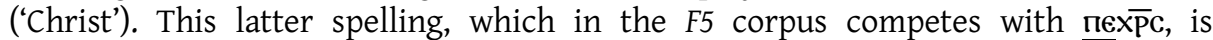
most certainly a reflection of the Bohairic practice, just like the abbreviations $\Phi \mp$

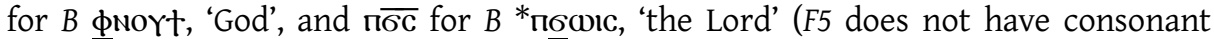
aspiration and thus the 'proper' $F 5$ forms of these words would be nNort and $\pi \times$ alc) ${ }^{27}$

- The scribe often doubles the letter $\mathrm{N}$ when it is morphemic (serving as the linkage marker, direct object marker, negative scope definer etc.) and precedes vocalic onsets - e.g. NT2H NNOYeI ('like someone') in verse 7.25. Sometimes, morphemic $\mathrm{N}$ is not doubled - e.g. мт2н Noүгоген ('like an untimely birth') in verse 15.8.

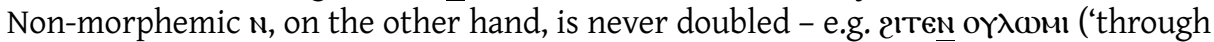
a man') at 1 Cor 15.21 and $2 \mathrm{~N}$ d.AdM ('in Adam') at 1 Cor 15.22.

- The scribe omits the non-morphemic initial syllabic nasal in the first-person singular form of the conjunctive, writing Td- rather than NTd- (1 Cor 7.25). In the F5 corpus, $\mathrm{N}$ is similarly omitted in codex MICH.AX (comprising the Investiture of Michael (cc 0488)), where Td- occurs eleven times, ${ }^{28}$ NTd- only once. ${ }^{29}$ In the F4 corpus, this omission is attested in P.Lond.Copt. 1.504 (comprising John 3.5-4.49), where Td- $^{-}$occurs twice, ${ }^{30}$ NTd- five times. ${ }^{31}$ On the other hand, the scribe of P.MorganLib. 265 does not omit the initial $\mathrm{N}$ in the first-person plural form of the

\footnotetext{
${ }^{27}$ To my knowledge, in Fayyūmic literary texts, the singular form of xalc is always abbreviated; the nonabbreviated form is attested in documents (see e.g. P.MoscowCopt. 2; 22; 25). For the reconstructed Bohairic form * owı, see L. Stern, Koptische Grammatik (Leipzig: Weigel, 1880) 65 (\$133).

${ }^{28}$ C. D. G. Müller, Die Bücher der Einsetzung der Erzengel Michael und Gabriel (Corpus Scriptorum Christianorum Orientalium 225; Leuven: Secrétariat du CorpusSCO, 1962) 3.19; 7.16; 9.13, 14, 19; 25.15 (bis); 29.11; 31.21; 41.17; 43.19 .

${ }^{29}$ Müller, Bücher, 43.18 .

${ }^{30}$ W. E. Crum and F. G. Kenyon, 'Two Chapters of St. John in Greek and Middle Egyptian', JTS 1 (1900) 415-33, at 427 (John 4.7), 431 (John 4.34).

${ }^{31}$ Crum and Kenyon, 'Two Chapters of St. John', 425 (John 3.30), 427 (John 4.10), 429 (John 4.15 (bis)), 431 (John 4.34).
} 
conjunctive, writing NTEN- rather than TEN- (1 Cor 2.12). The latter spelling occurs in three manuscripts in the F5 corpus - viz. MICH.AX, codex B and the still unpublished papyrus codex comprising the Martyrdom of Paphnutius (cc 0294) and the Life of Onnuphrius (cc 0254). ${ }^{32}$

- In the expression mмN с)бам ммд = ('to be unable'), the initial syllabic nasal of the preposition $\mathbf{M M d}$ = is omitted, resulting in the spellings ммм œбаммач ('he is unable') at 1 Cor 2.14 and мmм o) бגMmaтen ('you [pl.] are unable') at 1 Cor 3.2. However, in the one instance where this expression is used with the affirmative existential - viz. oYan c) Gaм mMak ('you [sg.] are able') in verse 7.21 - the nasal is not omitted. Similarly, the negative existential is usually mMN (1 Cor $2.14 ; 3.2 ; 15.13)$ but is at least once spelled with the initial syllabic nasal omitted - viz. MN (1 Cor 3.11). ${ }^{33}$ The initial syllabic nasal is also omitted in the only occurrence of the phonologically reduced form of the possessive predicate MMNTE-, MMNTH= (derived from the negative existential mMN and the preposition NT€-, NTH=) - viz. mNt ('I do not have'), in verse 7.25 .

- The modal auxiliary of the conditional can be spelled either with or without the nasal sonorant - viz. a)dN and c)d. The former spelling - which is the norm in $\mathrm{F5}^{34}$ - occurs in all five instances when the modal auxiliary is preceded by the pronominal subject (1 Cor 7.28 (bis); 15.24 (bis), 27). In the two instances where the subject is nominal - viz.,1 Cor 3.4 and 15.28 - the morpheme is spelled a)d. ${ }^{35}$ This pattern (a)d before nouns, a)dN before pronouns) seems to be the same in P.Mich.inv. 158 (9) + P.MorganLib. 264.

- The form снвві ('to circumcise'; $S$ св̈вє, B сєві) and its cognates - viz. the construct form снввнт $=$ and the stative form снввноүт - deserve a special comment. This form also occurs in another F5 manuscript extracted from the covers of a Phantoou codex - viz. P.MorganLib. 267 (unpublished). However, yet another F5 manuscript - viz. P.Mich.inv. 158 (9) + P.MorganLib. 264 - always reads сүвві, сүввн-. These latter forms attest to the Fayyūmic scribal practice also reflected in TYBT ('fish') and aүва) ('shield') - namely, to represent the reduced vowel (i.e. schwa/ə/) with $\gamma$ in a closed stressed syllable, with $/ v /{ }^{36}$ as its coda. ${ }^{37}$ P.MorganLib. 265 and 267 thus bear witness to an alternative practice, in which the schwa followed by /v/ in a closed stressed syllable is represented by $\mathrm{H}$. It is tempting to surmise that this difference in spelling - viz. CHBB (P.MorganLib. 265 and 267) vs cYBBi (P.Mich.inv. 158 (9) + P.MorganLib. 264) - indicates that different Fayyūmic scriptoria maintained different scribal habits. ${ }^{38}$

\footnotetext{
${ }^{32}$ This codex is part of the Schøyen Collection (inventory numbers: MS 245/27, MS 245/238 and MS 245/264). An editio princeps is under preparation by Ivan Miroshnikov and Alexandros Tsakos.

${ }^{33}$ See also verse 15.12, in Part II of this article, and the discussion ad loc. in 'Notes on the Coptic Text' there.

${ }^{34}$ See W.-P. Funk, 'Koptische Isoglossen im oberägyptischen Raum. 3. Die Konjugationsformen des Konditional. 4. Die Pluralform des absoluten Possessivpronomens', ZÄS 114 (1987) 45-54, at 47.

${ }^{35}$ In the latter instance, since c)d is written at the end of the line, the missing $\mathrm{N}$ could have been represented with the supralinear stroke, which could have faded; however, since, a few lines above, the supralinear stroke after a)d (verse 15.27) is perfectly visible, I am inclined to think that, in verse 15.28, the manuscript reads a)d, not a)d".

${ }^{36}$ For a critique of the traditional phonological interpretation of $\mathrm{B}$ as /b/, see C. H. Reintges, Coptic Egyptian (Sahidic Dialect): A Learner's Grammar (Study Books of African Languages 15; Cologne: Köppe, 2018 ${ }^{2}$ ) 20-1.

${ }^{37}$ The use of $Y$ in these words probably indicates that, due to its proximity to a labial consonant, the schwa comes to resemble $/ \mathrm{u} /$.

${ }^{38}$ Admittedly, it seems impossible to ascertain where these three manuscripts were produced. However, the little that we do know about their provenance gives no reason to believe that any two of them could have been copied in the same scriptorium. Thus, unlike P.MorganLib. 265 and 267, P.Mich.inv. 158 (9) + P.MorganLib. 264 is not part of the Phantoou discovery. While codex MICH.BH (from whose covers P.MorganLib. 267 was extracted)
} 
- With regard to the schwa followed by a tautosyllabic 2, the scribes of the F5 manuscripts had three strategies: sometimes, the schwa is represented by a (e.g. това2, 'to entreat'), sometimes it has no graphic representation (Тов2); in late manuscripts, the schwa is occasionally represented with a supralinear stroke (тов $\overline{2})$. The scribe of P.MorganLib. 265 seems to be consistent in opting for the second approach, writing

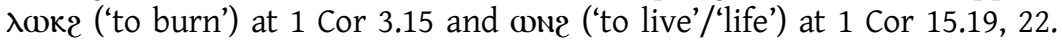

- At 1 Cor 15.9, the preposition whose usual spelling is oүTe- is spelled oy $\Delta \epsilon^{-}$. In the F5 corpus, this spelling likewise occurs in P.Mich.inv. 158 (9) + P.MorganLib. 264 (at Rom 2.15, although at Eph 3.8 this manuscript also has ortє-). The form oY $\Delta €-$ is also found in codex C (at 1 Cor 15.9), in Sahidic manuscripts (including those produced in the Fayyūm) ${ }^{39}$ and some of the first-millennium B5 manuscripts. ${ }^{40}$ This spelling could perhaps be explained by the scribe drawing an analogy with the Greek loan

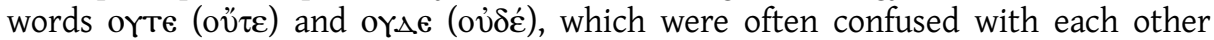
due to the lack of contrast between voiced /d/ and voiceless /t/ in Coptic.

- The word mncoc ('then') occurs twice in the manuscript (1 Cor 15.6, 7), in both cases spelled with omicron. In the F5 corpus, the prepersonal form of $\mathrm{M}(\epsilon) \mathrm{N}(\mathrm{N \epsilon}) \mathrm{Cd}-\mathrm{may}$ be

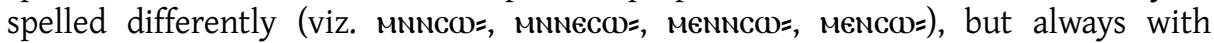
omega. It is worth noting, however, that the form mnNCo= occurs in codex $\mathrm{C}^{41}$ as well as in a number of Sahidic manuscripts produced in the Fayyūm - e.g. MICH.AL (= P.MorganLib. 51), ${ }^{42}$ MICH.AZ (= P.MorganLib. 116) ${ }^{43}$ and MICH.BF (= P.MorganLib. $173+417){ }^{44}$

comes from the scriptorium of Toutōn, MICH.BM does not, nor is there any indication that the bindings of MICH.BH and MICH.BM could have been produced at the same bindery (cf. my discussion of the provenance of P.MorganLib. 265 in the following section).

${ }^{39}$ See e.g. MICH.AQ (the Acts of John by Pseudo-Prochorus (cc 0565)), p. 7, col. i, 1. 6.

${ }^{40}$ See e.g. MACA.CJ (the Encomium on George ascribed to Theodotus of Ancyra (cc 0390)); I. Balestri and H. Hyvernat, Acta Martyrum (Corpus Scriptorum Christianorum Orientalium 86; Paris: Typographeum reipublicae, 1924) 189.20.

${ }^{41}$ See Rom 11.31; 1 Cor 15.6, 7, 23; Heb 7.2, 27; 10.17.

${ }^{42}$ According to its colophon (A. van Lantschoot, Recueil des colophons des manuscrits chrétiens d'Egypte, vol. I: Les colophons coptes des manuscrits sahidiques (2 vols.; Bibliothèque du Muséon 1; Leuven: Istas, 1929) I.48-9), codex

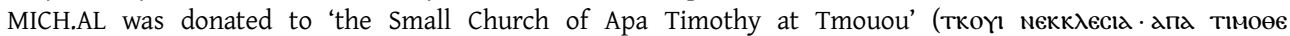
NTMoYoY; for Tmouou, undoubtedly located in the Fayyūm, see S. Timm, Das christlich-koptische Ägypten in arabischer Zeit (6 vols.; Beihefte zum Tübinger Atlas des Vorderen Orients. Reihe B (Geisteswissenschaften) 41.1-6; Wiesbaden: Reichert, 1984-92) vi.2716). Eventually, it was deposited at the Monastery of the Archangel Michael. MICH.AL comprises the Annual Lectionary (see Depuydt, Catalogue, I.69-81; D. Atanassova, 'The Primary Sources of Southern Egyptian Liturgy: Retrospect and Prospect', Rites and Rituals of the Christian East (Eastern Christian Studies 22; ed. B. Groen, D. Galadza, N. Glibetic and G. Radle; Leuven: Peeters, 2014) 52-3). In this codex, the form mwnco= occurs at least twice: see MICH.AL, fol. 16v, col. ii, 1l. 18-19 (= Heb 7.27); fol. $74 \mathrm{v}$, col. i, 1l. 13-14 (= 1 Cor 12.28). The references are from R. Kasser, Compléments au dictionnaire copte de Crum (Bibliothèque d'Études Coptes 7; Cairo: Institut français d'archéologie orientale, 1964) 52a.

${ }^{43}$ Codex MICH.AZ was deposited at the Monastery of the Archangel Michael; it comprises a miscellany of seven works in honour of the Archangel Michael. For the form mwnco= in codex MICH.AZ, see D. Groddek, T. Lindken and H. Schäfer, Ein wildes Volk ist es ... Predigt (Ps.-Athanasius) über Lev 21,9, Ex 19,22, den Erzengel Michael und das Weltenende unter arabischer Herrschaft (Corpus Islamo-Christianum, Series Coptica 1; Altenberge: Oros, 2004) 35-6.

${ }^{44}$ According to its colophon (Van Lantschoot, Colophons, I.31-3), codex MICH.BF was produced in 'Ptepouhar in the Fayyūm' (птепоүгар епїом; for this toponym, see Timm, Ägypten, Iv.2060-1) and then donated to the Monastery of the Archangel Michael. MICH.BF comprises the Life of Samuel of Kalamun (cc 0216), by the presbyter Isaac of Kalamun; the Homily on the Patriarch Joseph (cc 0138), attributed to Ephrem; and the Jeremiah Apocryphon (cc 0032) (see Depuydt, Catalogue, i.357-9). For the form mnnco= in codex MICH.BF, see K. H. Kuhn, 'A Coptic Jeremiah Apocryphon', Le Muséon 83 (1970) 95-135, 291-350, at 129.5, 130.16, 308.18, 325.10-11; A. Alcock, The Life of Samuel of Kalamun by Isaac the Presbyter (Warminster: Aris and Phillips, 1983) 3.26, 30.24. 
Of the morphological features of P.MorganLib. 265, the most remarkable is the relative perfect form $6 \mathrm{Tda}=$, which occurs twice in the extant text (1 Cor 2.12, 16). In the history of Coptic linguistics, the reasons behind the occasional doubling of the letter $a$ in the F5 perfect conjugation base have been a matter of debate. While Ludwig Stern considered the

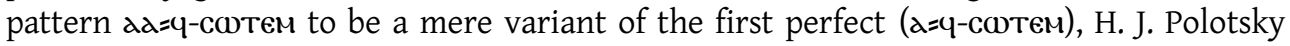
argued that $\mathbf{d \alpha}=\mathrm{y}$-соттем is, in fact, a special form of the second perfect, an interpretation later endorsed by Walter C. Till and Georg Steindorff. ${ }^{45}$ However, as Funk noted in 1995, this interpretation does not take into account those instances in the F5 corpus where the doubled a occurs in relative perfect. ${ }^{46}$ This Gordian knot was severed in the latest instalment of Funk's F5 concordance, where two homonymous morphemes are distinguished, one occurring in the second perfect, ${ }^{47}$ the other in the relative perfect. ${ }^{48}$ P.MorganLib. 265 is thus an important new witness of the second morpheme. Its importance lies in the fact that, in this manuscript, the relative form occurs for the first time with the spelling $6 \mathrm{Tdd}=$ (rather than NTdd=). Moreover, P.MorganLib. 265 is the only known F5 manuscript where the relative perfect with the doubled a appears in the 'glose' of a cleft sentence. In fact, it seems that, in all other contexts, P.MorganLib. 265 employs the form NTd-, NTd=, which may indicate that, in this manuscript, the form eTdd= was reserved exclusively for cleft sentences.

The following two morphological features of P.MorganLib. 265 are also worth mentioning:

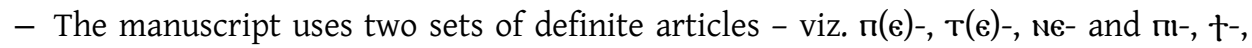
$\mathrm{Nl}^{-}$. As I have already noted, in the plural the definite article is predominantly $\mathrm{Nl}^{-}$, while Nє- occurs only twice, and only in the expression ката мєграфн ('according to the scriptures'). In the singular, the situation is reversed: the text normally employs $\Pi(\epsilon)$ - and $\mathrm{T}(\mathrm{\epsilon})$-, while $\mathrm{m}$ - occurs only five times (1 Cor 2.14; 7.16, 22 (bis); 15.5) and †only once (1 Cor 7.28). As far as I can tell, the use of one of the two sets of articles is not conditioned syntactically, nor is there any discernible difference in meaning between them. ${ }^{49}$

\footnotetext{
${ }^{45}$ Stern, Grammatik, 215 (\$374), 291 (\$392); G. Steindorff, Lehrbuch der koptischen Grammatik (Chicago: University of Chicago Press, 1951) 157 (\$339); W. C. Till, Koptische Dialektgrammatik (Munich: Beck, 1961 ${ }^{2}$ ) 57 (\$264); H. J. Polotsky, Collected Papers (Jerusalem: Magnes, 1971) 99-101, 175, 198-9.

${ }^{46}$ Funk, 'Gedanken', 100. In addition to several manuscripts of the $F 5$ corpus, the doubled a occurs in relative perfect in the Sahidic manuscripts from Phantoou - see e.g. P.MorganLib. 117, fol. 8v, col. ii, 1l. 18-19 (חNaY

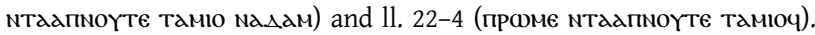

${ }^{47}$ In addition to several manuscripts of the $F 5$ corpus, the second perfect conjugation base ad-, da = also occurs in codex C (1 Cor 15.21; 1 Thess 2.3; Heb 9.24) and in several Sahidic manuscripts from Phantoou (e.g. MICH.CC, MICH.BP). For the latter, see K. H. Kuhn, 'Pseudo-Shenoute on Christian Behaviour', Le Muséon 71 (1958) 359-80, at 361; idem, A Panegyric on John the Baptist Attributed to Theodosius, Archbishop of Alexandria (Corpus Scriptorum Christianorum Orientalium 268; Leuven: Secrétariat du CorpusSCO, 1966) xv; M. Müller and S. Uljas, Martyrs and Archangels: Coptic Literary Texts from the Pierpont Morgan Library (Studien und Texte zu Antike und Christentum 116; Tübingen: Mohr Siebeck, 2019) 323.

${ }^{48}$ In these instances, the conjugation base $d d=$ is preceded by the relative converter. There are rare instances, however, where $\mathrm{NTdd}=$ must be interpreted as second perfect - see e.g. P.MorganLib. 415 (a fragment from the

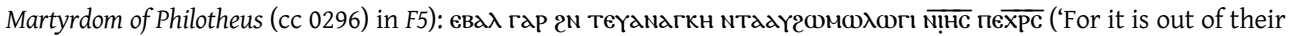
necessity that they confessed Jesus Christ'); the Coptic text is from L. Saint-Paul Girard, 'Un fragment fayoumique du martyre de Saint Philothée', Bulletin de l'Institut français d'archéologie orientale 22 (1922) 105-13, at 106 (recto, col. ii, 11. 12-14).

${ }^{49}$ Compare, for instance, the statements about 'the ( $\left.\mathrm{m}-\right)$ psychical person' (1 Cor 2.14), 'the ( $\left.\boldsymbol{n}^{-}\right)$man' (1 Cor 7.26), and 'the ( $\left.t^{-}\right)$virgin' (1 Cor 7.28). All three statements are generic, yet at 1 Cor 2.14 and 1 Cor 7.28 the article is from one set and at 1 Cor 7.26 from the other.
} 
- The manuscript also attests to two competing forms for causative infinitive - viz. трє-, трє $=$ and $\mathbf{~} \epsilon^{-}$, Tє $=$. The pattern трє-, трє $=$occurs six times: twice in the purpose clause construction 6 -трє- (1 Cor $7.26 ; 15.9)$, twice in the negative causative imperative мпє

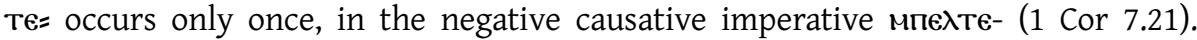
This datum seems to support Funk's observation that, in F5, the pattern TE-, TE= was out-competed by трє-, трє = and that, as a rule, its use was restricted to the

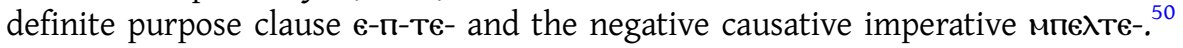

The treatment of Greek loanwords in P.MorganLib. 265 reflects the standard practices of the Fayyūmic scriptoria: that is, our scribe is consistent in representing all Greek

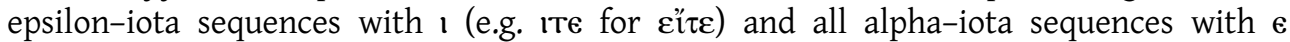

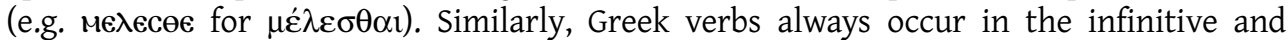
are always derived by means of the light verb $\epsilon \lambda$ - (e.g. e $\lambda \_$okimazın). The following features of the manuscript are worthy of note:

- Although the scribe of P.MorganLib. 265 often misspells Greek words - replacing $\omega$

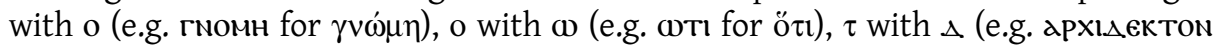
for $\dot{\alpha} \rho \chi \imath \tau \dot{\varepsilon} \kappa \tau \omega v)$ etc. - he never uses the monogram + for the tau-iota sequences in

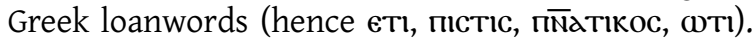

- The verb i $\pi$ o $\tau \alpha \sigma \sigma \varepsilon \sigma \theta \alpha$ l ('to be subject'), which occurs in P.MorganLib. 265 six times, is remarkable with respect to its spelling. As Funk observes, in Bohairic and

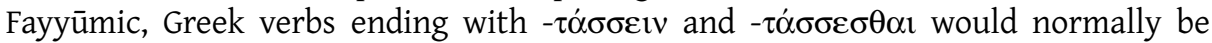
spelled -Tazın or -Tazecee. ${ }^{51}$ This observation is confirmed by P.MorganLib. 265, where, five out of six times, the verb is spelled гнпотаzесөє, yet once it is spelled гнпотасесеє, which indicates that the scribe had difficulty distinguishing voiced /z/ from voiceless /s/. It is worth noting, however, that at least one manuscript that can be considered for inclusion into the F5 corpus - viz. P.MorganLib. 268 goes against this tendency, reading eүпотасceceє (at 1 Cor 14.32, 34). However, given that the orthography of P.MorganLib. 268 is often at odds with the F5 standard - for example, in this manuscript, the full (stressed) form of the possessive predicate is oYanT = (rather than oүanTH=) - the form 2үпотаccecee should probably be explained by the scribe's insufficient acquaintance with the orthographic norm. ${ }^{52}$

- Another medio-passive infinitive that occurs in P.MorganLib. 265 is $\mu \varepsilon \dot{\lambda} \lambda \varepsilon \sigma \theta \alpha$ ('to be an object of care'). In the Greek text of the New Testament, the verb $\mu \varepsilon \dot{\lambda} \varepsilon 1 v$ occurs only in the active voice. It is, therefore, rather remarkable that, at 1 Cor 7.21, P.MorganLib. 265 employs the medio-passive form; a similar 'predilection for the longer form' was recently detected by Funk in the 'Curzon Catena' (P.Lond.Copt.

\footnotetext{
${ }^{50}$ W.-P. Funk, 'Some Lesser Known Prospective and Causative Conjugation Forms in Coptic Dialects and the Problem of Their Ancestry', Journal of the Canadian Society for Coptic Studies 9 (2017) 53-66, at 61. In addition to the two uses given by Funk, there are also at least two F5 manuscripts where Tє-, TE= is conjugated - viz. P.MorganLib. 259 (see Depuydt, Catalogue, I.449 (at Ps 15.3)) and P.Mich.inv. 158 (9) + P.MorganLib. 264 (see W. H. Worrell, 'Fayumic Fragments of the Epistles', Bulletin de la Société d'archéologie copte 6 (1940) 127-39, at 132 (Eph 1.22)).

${ }^{51}$ W.-P. Funk, 'Differential Loan across the Coptic Literary Dialects', Greek Influence on Egyptian-Coptic: Contact-Induced Change in an Ancient African Language (ed. E. Grossman, P. Dils, T. S. Richter and W. Schenkel; Lingua Aegyptia: Studia Monographica 17; Hamburg: Widmaier, 2017) 369-97, at 378 n. 40.

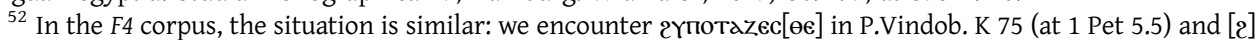
Yпотасес[өє] in P.Vindob. K 8691 (at 1 Pet 2.13); see W. C. Till, 'Wiener Faijumica', Le Muséon 49 (1936) 169-217, at 194 and 196. However, in Oxford, Bodleian Library, Ms.Copt.g.97(P) (at 1 Cor 14.34), the length of the lacuna dictates that we should restore eүחо[тас]çece€ (for a discussion of this fragment, see Part II of this article).
} 
2.249), one of the key witnesses to the medieval Bohairic (dialect B5) of the first millennium. ${ }^{53}$ Interestingly, in the Bohairic New Testament (bo), the active voice of the Greek original is also occasionally rendered with mє not at 1 Cor 7.21, where all the witnesses use the active form.

- The word YrxHкoc, which occurs in P.MorganLib. 265 at 1 Cor 2.14, also occurs in one other manuscript of the F5 corpus - viz. P.Vindob. K $3280+\mathrm{K} 3921+\mathrm{K} 9311$ - where it is similarly spelled with $\mathrm{H}$. It is tempting to suggest that Yrxнкос was the standard F5 spelling of $\psi v \chi$ « support from the fact that, in the F5 corpus, some of the words formed with the prefix $\alpha \rho \chi$ - are similarly spelled with $\mathrm{H}^{54}$ - viz. дрхндггє France, Copte $163^{1}$ fol. 1 (comprising an otherwise unknown martyrdom) and MICH.AX), ${ }^{55}$ архнєпіскопос (in P.Carlsberg 300, comprising De incredulitate (cс 0013) and De providentia (cc 0012), both attributed to the fictitious Agathonicus of Tarsus), ${ }^{56}$ архнпласма (in MICH.AX) ${ }^{57}$ and арxнстра_ıкос (in MICH.AX). ${ }^{58}$

- The F5 corpus is divided on the pluralisation of the noun $\dot{\varepsilon} v \tau \mathrm{\lambda} \boldsymbol{\lambda}$. Two manuscripts viz. codex B (at John 14.21) ${ }^{59}$ and P.Mich.inv. 158 (9) + P.MorganLib. 264 (at Rom 13.9) - employ the singular form (єNTO入н), specifying the number of the noun only by means of the article. Two other manuscripts - viz. P.Carlsberg 300 and Pushkin State Museum of Fine Arts, I.1.6.637 - also add the plural marker -oy. ${ }^{60}$ P.MorganLib. 265, which uses the form enто入но (at 1 Cor 7.19), belongs to the second group. ${ }^{61}$

- The F5 corpus is also divided on the spelling of the conjunction iv $\alpha$. Some manuscripts always read and (e.g. codex B and National Library of France, Copte $163^{1}$ fol. 1), others always 2indN (e.g. P.MorganLib. 259 and 261). ${ }^{62}$ P.MorganLib. 265 seems to belong in the former group. It is worth noting, however, that, in both instances where and occurs in this manuscript (viz. 1 Cor 2.12; 15.28), it is followed by the initial $\mathrm{N}$ of the conjunctive. It is thus possible that the form aind in these two cases is due to 'phonetic' haplography ${ }^{63}$ and that, elsewhere in the manuscript, the

\footnotetext{
${ }^{53}$ Funk, 'Differential Loan', 379.

${ }^{54}$ Interestingly, this tendency did not affect the words $\dot{\alpha} \rho \chi \imath \varepsilon \dot{\varepsilon} \kappa \tau \omega v(1$ Cor 3.10) and $\dot{\alpha} \rho \chi 1 \varepsilon \rho \varepsilon v \dot{s}$; the latter is attested in three F5 manuscripts - viz. codex B (at Matt 26.14 and Mark 8.31), P.MorganLib. 261 (at Mark 14.1) and National Library of Russia, Ф. 920, № 53 (at Mark 14.53, 60, 61, 63; 15.10, 11, 31) - in all of them spelled with 1. See Bouvarel-Boud'hors, 'Fragments', 111; Chassinat, 'Fragments', 199; Depuydt, Catalogue, I.453; A. I. Elanskaya, Коптские рукописи Государственной публичной библиотеки имени M. Е. Салтыкова-Щедрина [Coptic Manuscripts in the M. E. Saltykov-Shchedrin State Public Library] (Палестинский сборник [Palestinsky Sbornik] 20; Leningrad: Nauka, 1969) 101-4.

${ }^{55}$ S. Bacot, 'Une nouvelle "passion” copte fayoumique (Paris, BNF, Copte 163¹, f.1)', Le Muséon 112 (1999) 30113, at 307 (verso, col. ii, 1. 4); Müller, Bücher, 3.5, 11.25, 27.25, 41.11, 31-2, 45.7, 49.34 (read архнаггєлос).

${ }^{56}$ M. Andersen, B. Holmen and J. Tait, 'Palaeographical and Codicological Notes to Supplement Erichsen's Edition of the Copenhagen Fayumic Manuscript of Agathonicus: P. Carlsberg 300', Enchoria 25 (1999) 1-19, at 11 (fol. 6b, 1l. 8-9).

${ }^{57}$ Müller, Bücher, 13.4, 5, 6, 13, 24, 17.28 .

${ }^{58}$ Müller, Bücher, 23.5, 41.8.

${ }^{59}$ L. T. Lefort, Les manuscrits coptes de l'Université de Louvain. I: Textes littéraires (Leuven: Bibliothèque de l'Université, 1940) 85.

${ }^{60}$ Andersen, Holmen and Tait, 'Notes', 9 (fol. 4b, 1. 24); A. I. Elanskaya, The Literary Coptic Manuscripts in the A. S. Pushkin State Fine Arts Museum in Moscow (VC Supplements 18; Leiden: Brill, 1994) 416 (at Ps 118/119.66).

${ }^{61}$ Admittedly, since the occurrences of $\dot{\varepsilon} v \tau 0 \lambda \eta \dot{~ i n ~ t h e ~ p l u r a l ~ a r e ~ r a t h e r ~ f e w, ~ w e ~ c a n n o t ~ k n o w ~ h o w ~ c o n s i s t e n t ~}$ any of the cited manuscripts were in their (non-)use of -oy. Cf. especially Codex A, whose scribe, in the same

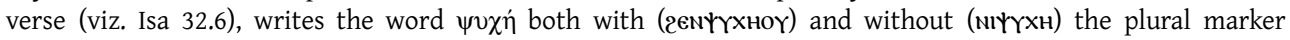
(Chassinat, 'Fragments', 181).

${ }^{62}$ As Funk ('Differential Loan', 373) notes, the addition of the final /n/ in qwan is difficult to explain.

${ }^{63}$ For this phenomenon, see Funk and Smith, 'John 10:7-13:38 in Subachmimic', 68.
} 
word was spelled aINan. In fact, there are at least two manuscripts in the 55 corpus (viz. codex A and P.Mich.inv. 158 (9) + P.MorganLib. 264) that usually use qiNan but occasionally have aind - albeit always before the conjunctive. ${ }^{64}$

- Another Greek loanword that perhaps deserves to be mentioned here is the personal

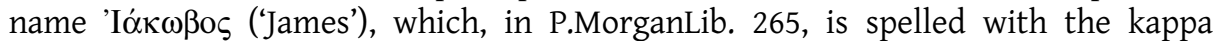
doubled - viz. laкковос (1 Cor 15.7). A case can be made that this was, in fact, the standard spelling of the name in F5. Apart from P.MorganLib. 265, the form with the doubled kappa occurs in at least four manuscripts: P.Vindob. K 10113 (at Mark 16.1: Іакков [ос]), ${ }^{65}$ codex B (at Matt 13.55: Іаккювос), ${ }^{66}$ P.Carlsberg 300 (fol. 7a, 11. 8-9: гаккळвос) ${ }^{67}$ and MICH.AX (гакковос). ${ }^{68}$

Finally, P.MorganLib. 265 provides scholars of the Coptic language with valuable lexicographic data. In a number of cases, this manuscript attests to the use of a lexeme or a form thereof otherwise unattested in the $F 5$ corpus. Fortunately, though the manuscript itself has been hitherto unpublished, most of these forms were registered in Crum's dictionary, who consulted P.MorganLib. 265 via Hyvernat's facsimile - viz. and- (phonologically reduced form of $\mathrm{\omega N}$, 'stone', occurring in the compound aNammeel, 'precious stone'), ${ }^{69}$ apot ('milk'), ${ }^{70}$ KadNc= ('to be buried', prepersonal form of the verb whose absolute form is unattested), ${ }^{71}$ cady- (prenominal form of the verb $\operatorname{co}(\omega) \varphi$, 'to defile'), ${ }^{72}$ oydale ('farmer', occurring in the compound ienorade, 'tillage') 73 and $20 \% 2 \mathrm{H}$ ('untimely birth'). ${ }^{74}$ Two otherwise unattested forms were unknown to Crum - viz. снввноүт (stative of снвві, 'to circumcise') and снввнт= (prepersonal form of the same verb). P.MorganLib. 265 also bears witness to several forms that are rather poorly attested in the F5 corpus for example, $2 \lambda \boldsymbol{\lambda} \lambda \mathbf{l}$ (absolute form of the imperative of the verb $1 \lambda \mathbf{l}$, 'to do'; not registered in Crum's dictionary) otherwise occurs only once, in P.Vindob. K $3280+\mathrm{K} 3921+\mathrm{K} 9311$ (at 1 Cor 16.1); keen ('thing') only once, in P.Mich.inv. 158 (9) + P.MorganLib. 264 (at Rom

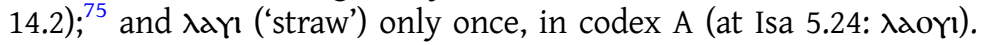

\footnotetext{
${ }^{64}$ Interestingly, National Library of Russia, Ф. 920, № 53 exhibits a different orthographic tendency, with

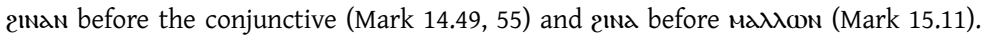

${ }^{65}$ W. C. Till, 'Faijumische Bruchstücke des Neuen Testamentes', Le Muséon 51 (1938) 227-38, at 233.

${ }^{66}$ Admittedly, elsewhere in this codex (viz. at Mark 9.2), the name is spelled ïaковос.

${ }^{67}$ Andersen, Holmen and Tait, 'Notes', 12.

${ }^{68}$ Müller, Bücher, 35.28.

${ }^{69}$ Crum's 'and-BF' at Coptic Dictionary, 524a must be based on 1 Cor 3.12 in P.MorganLib. 265, even though he does not refer to this passage explicitly.

${ }^{70}$ Crum, Coptic Dictionary, 58b (with reference to 1 Cor 3.2 in P.MorganLib. 265). In addition to apor, Crum also

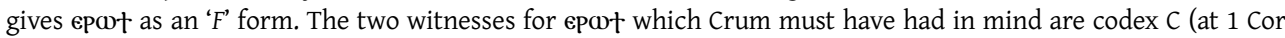
9.7) and the Saint Petersburg codex of the apocryphal acts of the apostles (see O. von Lemm, 'Koptische apokryphe Apostelacten', Bulletin de l'Académie impériale des sciences de St.-Pétersbourg 1, ser. IV (1890) 509-81, at 542). Since both these witnesses are littered with Sahidicisms (for the latter manuscript, see I. Miroshnikov, 'The Coptic Versions of the Acts of Andrew and Matthias (CANT 236), with an Edition of IFAO Copte inv. 132', Le Muséon 132 (2019) 291-328, at 306-7), it seem reasonable to surmise that, of the two ' $F$ ' forms in Crum, only aport was the standard spelling in $F 5$.

${ }^{71}$ Crum, Coptic Dictionary, 120 b (with reference to 1 Cor 15.4 in P.MorganLib. 265).

${ }^{72}$ Crum, Coptic Dictionary, 378b (with reference to 1 Cor 3.17 in P.MorganLib. 265).

${ }^{73}$ Crum, Coptic Dictionary, 473a (with reference to 1 Cor 3.9 in P.MorganLib. 265).

${ }^{74}$ The two sources of Crum's '20Ү2н F' at Coptic Dictionary, 739b are 1 Cor 15.8, in either P.MorganLib. 265 or codex C (which happens to have the same form), or perhaps even both, and Eccl 6.3, in the sole witness of dialect F7, the codex housed at the Staats- und Universitätsbibliothek Hamburg under inventory number Pap.Bil. 1. See B. J. Diebner and R. Kasser, Hamburger Papyrus Bil. 1. Die alttestamentlichen Texte des Papyrus Bilinguis 1 des Staats- und Universitätsbibliothek Hamburg (Cahiers d'Orientalisme 18; Geneva: Cramer, 1989) 284 (20Y2H).

${ }^{75}$ Outside the 55 corpus, the form $\kappa \epsilon \in \mathrm{NI}$ is attested in codex C; see 1 Cor 15.27 (ter), 28 (bis); Heb 1.2; 2.8 (ter), 10 (bis); 7.2; 9.22.
} 
While Crum's inventory of forms attested in P.MorganLib. 265 is more or less complete, the data provided by P.MorganLib. 265 can still be used to supplement existing dictionaries and grammars with regard to the use of several words and constructions in F5. For example, P.MorganLib. 265 has two instances of the preverbal modifier єлпкє-, 'also' (1 Cor 15.15, 29), for which Crum provides only Sahidic and Bohairic attestations. ${ }^{76}$

It is also worth noting that, in one instance, P.MorganLib. 265 leaves Coptic lexicographers disappointed. At 1 Cor 7.29, bo reads псноү мпюрч пе ('it is the time of withdrawal'), and there can be little doubt that the phrasing of fa was similar (with F5 oralc) corresponding to B5 cHoY). Unfortunately, the letters following $\alpha$ are lost in the lacuna, and thus we cannot know whether B5 OPY was subject to lambdacism in $F 5 .^{77}$

\section{Provenance and Date}

Since P.MorganLib. 265 is written in F5, a dialect of the Fayyūm, and since it was extracted from the covers of a manuscript which belonged to a monastery in the Fayyūm, we can be fairly certain that P.MorganLib. 265 was copied in the Fayyūm. Nevertheless, it seems impossible to ascertain where exactly in the Fayyūm it was produced. According to Petersen, the binding of MICH.BM (from which P.MorganLib. 265 was extracted) "very clearly' comes from the same bindery as those of MICH.AB, MICH.AR and MICH.AU. ${ }^{78}$ Since, according to their colophons, these three codices were donated to the Monastery of the Archangel Michael, it is not impossible that this monastery was also where the codices were copied and bound. However, this hypothesis is made problematic by the fact that MICH.AR seems to have been originally donated to a place different from the Monastery of the Archangel Michael. ${ }^{79}$ On the other hand, since one of the scribes of MICH.AB - viz. Isaac - resided in Ptepouhar, ${ }^{80}$ we might surmise that the binding of MICH.AB (along with those of MICH.AR, MICH.AU and MICH.BM) was produced there, too. Unfortunately, however, even if this surmise should be correct, we would still not know whether the scriptorium where P.MorganLib. 265 was produced and the bindery where it was later reused were situated in the same place.

The terminus a quo for P.MorganLib. 265 is provided by its dialect. According to Funk, the manuscripts of the F4 corpus were copied between the fourth and sixth centuries $\mathrm{CE}$, while the witnesses to F5 were produced from the sixth century until the turn of the millennium. ${ }^{81}$ The terminus ante quem is provided by the date of the binding of MICH.BM. According to the colophons of MICH.AB and MICH.AU, ${ }^{82}$ these manuscripts were donated

\footnotetext{
${ }^{76}$ Crum, Coptic Dictionary, 91b-92a. In the F5 corpus, eגmke- also occurs in codex B (at John 6.36) and P.Mich.inv. 158 (9) + P.MorganLib. 264 (at 2 Cor 9.12). All four of these instances were not yet known to Funk at the time he published his seminal article on preverbal modifiers, where the only Fayyūmic example (Heb 6.9) was from codex C (see W.-P. Funk, 'Zur Syntax des koptischen Qualitativs. II. Die koptischen Präverbale und ihr Gebrauch beim Qualitativ', ZÄS 105 (1978) 94-114, at 98).

${ }^{77}$ Crum (Coptic Dictionary, 528a) references the form apeq- attested in MICH.BE (comprising the Martyrdom of Mercurius (cc 0432) and the Encomium on Mercurius (cc 0002), the latter attributed to Acacius of Neocaesarea) as ' $F$ ', yet this manuscript, which admittedly exhibits a strong Fayyūmic tendency, does not belong to the $F 5$ corpus and thus cannot be admitted as evidence with regard to the orthography of this dialect.

${ }^{78}$ Petersen, 'Coptic Bookbindings', 158.

${ }^{79}$ According to the colophon of MICH.AR, the codex was originally donated to a topos similarly dedicated to Archangel Michael. The place name following птопос мпдрхаггелос михан $\lambda$ was then erased, and a different hand wrote eфantay over the erasure. See Van Lantschoot, Colophons, I.50, II.25.

${ }^{80}$ This is evident from the colophons of two other manuscripts copied by Isaac, MICH.BF and MICH.AT. The latter of them reads алак пє папа ісак псүнкірафос паї етфооп егоү(N) птепоүгар, 'I am Papa Isaac the writer, the one living in Ptepouhar' (Van Lantschoot, Colophons, I.29).

${ }^{81}$ Funk, 'Anfang des Johannesevangeliums', 34; idem, 'Formen und Funktionen', 17; idem, 'Gedanken', 94.

${ }^{82}$ As Van Lantschoot (Colophons, I.33, I.38) observes, these two colophons were inscribed by the same hand.
} 
to the Monastery of the Archangel Michael in the year 609 of the era of Diocletian $(=892 / 3$ $\mathrm{CE})$. Since, as Petersen observes, the date of the bindings of these two codices and MICH.BM is 'approximately the same, ${ }^{83}$ we can be certain that P.MorganLib. 265 was produced before $893 \mathrm{CE}$.

Within this date range, an earlier date (sixth or seventh century) seems more plausible than a later one. According to Kahle, P.MorganLib. 265 was produced 'not later than the seventh century'. ${ }^{84}$ Kahle's proposal receives support from the fact that the hand of P.MorganLib. 265 is similar to that of P.Vindob. K 8691, two parchment strips in dialect F4 that partially preserve 1 Pet $2.11-13,20-3$ and Jas $1.21-6 .{ }^{85}$ A documentary text in Middle Persian was written over the Fayyūmic, ${ }^{86}$ which provides a secure terminus ante quem for P.Vindob. K 8691 - viz. 629 CE (end of the Sasanian occupation of Egypt). ${ }^{87}$

Moreover, the paragraph mark signalling the beginning of 1 Cor 15.21 in P.MorganLib. 265 can be compared to those of the three Sahidic codices from the Monastery of Jeremias at Saqqara, housed at the Chester Beatty Library in Dublin. ${ }^{88}$ Thanks to the coins with which they were discovered, these manuscripts - numbered as sa 4 , sa 5 and sa 6 in the SMR (Schmitz-Mink-Richter) database - can be securely dated to $\mathrm{ca} 600 \mathrm{CE}{ }^{89}$

Acknowledgements. I wish to thank Anne Boud'hors, Hugh Houghton, Antti Marjanen and the anonymous reviewer of NTS for commenting on the previous drafts of this article, as well as Kenneth Lai for revising its English. I am especially grateful to Wolf-Peter Funk, who not only shared with me many of his unpublished findings but also kindly allowed me to consult the latest instalments of his concordances of the F4 and F5 corpora. Wolf-Peter's sudden passing on 18 February 2021 was an irreparable loss to Coptic dialectology.

${ }^{83}$ Petersen, 'Coptic Bookbindings', 162.

${ }^{84}$ Kahle, Bala'izah, I.284.

${ }^{85}$ For the dialect of P.Vindob. K 8691, see Funk, 'Anfang des Johannesevangeliums', 35. Both fragments were edited by Till ('Wiener Faijumica', 193-6), who was unable to identify the contents of the second fragment. This identification was later made by Kahle (Bala'izah, I.285).

${ }^{86}$ For an edition of the Middle Persian text, see D. Weber, 'Die Pehlevifragmente der Papyrussammlung der Österreichischen Nationalbibliothek in Wien', Festschrift zum 100-jährigen Bestehen der Papyrussammlung der Österreichischen Nationalbibliothek: Papyrus Erzherzog Rainer (P. Rainer Cent.). Textband (Vienna: Brüder Hollinek, 1983) $215-28$, at $226-7$.

${ }^{87}$ It is worth noting that P.Vindob. K 8691 is housed together with P.Vindob. G 3098, a small parchment fragment preserving Matt 26.14-15, 33 in Sahidic. Here, a Middle Persian text was similarly written over the Coptic, which means that this fragment must also predate $629 \mathrm{cE}$.

${ }^{88}$ See the drawings in T. Petersen, 'The Paragraph Mark in Coptic Illuminated Ornament', Studies in Art and Literature for Belle da Costa Greene (ed. D. Miner; Princeton: Princeton University Press, 1954) 295-330, at 299 (nos. 9, 10 and 11).

${ }^{89}$ See H. Thompson, ed., The Coptic Version of the Acts of the Apostles and the Pauline Epistles in the Sahidic Dialect (Cambridge: Cambridge University Press, 1932) ix-X, xix-xx.

Cite this article: Miroshnikov I (2022). A New Witness to the Fayyūmic Version of First Corinthians (P.MorganLib. 265). Part I: Notes on Codicology, Language, Provenance and Date. New Testament Studies 68, 89-104. https:// doi.org/10.1017/S002868852100028X 